\title{
Supply chain dynamism, information sharing, inter-organisational relationships and supply chain performance in the manufacturing sector
}

\begin{tabular}{|c|c|}
\hline \multicolumn{2}{|c|}{$\begin{array}{l}\text { Authors: } \\
\text { Moipone W. Mashiloane }{ }^{1} \\
\text { Chengedzai Mafini }^{1} \text { (1) } \\
\text { Raborale D.I. Pooe }^{2}\end{array}$} \\
\hline \multicolumn{2}{|l|}{ Affiliations: } \\
\hline \multicolumn{2}{|c|}{$\begin{array}{l}{ }^{1} \text { Department of Logistics, } \\
\text { Faculty of Management } \\
\text { Sciences, Vaal University } \\
\text { of Technology, South Africa }\end{array}$} \\
\hline \multicolumn{2}{|c|}{$\begin{array}{l}{ }^{2} \text { Department of Business } \\
\text { Management, College of } \\
\text { Business and Economics, } \\
\text { University of Johannesburg, } \\
\text { South Africa }\end{array}$} \\
\hline \multicolumn{2}{|c|}{$\begin{array}{l}\text { Corresponding author: } \\
\text { Chengedzai Mafini, } \\
\text { chengedzai@hotmail.com }\end{array}$} \\
\hline \multicolumn{2}{|c|}{$\begin{array}{l}\text { Dates: } \\
\text { Received: } 29 \text { Aug. } 2017 \\
\text { Accepted: } 23 \text { Apr. } 2018 \\
\text { Published: } 26 \text { July } 2018\end{array}$} \\
\hline \multicolumn{2}{|c|}{$\begin{array}{l}\text { How to cite this article: } \\
\text { Mashiloane, M.W., Mafini, C. } \\
\text { \& Pooe, R.D.I., 2018, 'Supply } \\
\text { chain dynamism, information } \\
\text { sharing, inter-organisational } \\
\text { relationships and supply } \\
\text { chain performance in the } \\
\text { manufacturing sector', } \\
\text { Acta Commercii 18(1), a547. } \\
\text { https://doi.org/10.4102/ } \\
\text { ac.v18i1.547 }\end{array}$} \\
\hline \multicolumn{2}{|c|}{$\begin{array}{l}\text { Copyright: } \\
\text { (c) 2018. The Authors. } \\
\text { Licensee: AOSIS. This } \\
\text { is licensed under the } \\
\text { Creative Commons } \\
\text { Attribution License. }\end{array}$} \\
\hline \multicolumn{2}{|l|}{ Read online: } \\
\hline 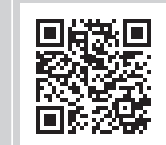 & $\begin{array}{l}\text { Scan this QR } \\
\text { code with your } \\
\text { smart phone or } \\
\text { mobile device } \\
\text { to read online. }\end{array}$ \\
\hline
\end{tabular}

Orientation: Manufacturing supply chains in South Africa are susceptible to various internal and external threats that continue to suppress their performance. Information is required that can be used by firms in such environments to overcome the existing threats and improve their supply chains.

Research purpose: This study sought to examine the relationship between supply chain dynamism, information sharing and inter-organisational relationships and supply chain performance in the manufacturing sector in South Africa.

Motivation for the study: There is a gap in literature on the linkage between supply chain dynamism, information sharing and inter-organisational relationships and supply chain performance in the South African manufacturing sector.

Research design, approach and method: Empirical data were collected from a purposive sample of 340 supply management professionals recruited from 31 manufacturing firms based in Gauteng Province. Data were analysed using structural equation modelling, which involved a confirmatory factor analysis and hypotheses tests.

Main findings: The results indicate a significant positive relationship between supply chain dynamism and both information sharing and inter-organisational relationships; between information sharing and both inter-organisational relationships and supply chain performance; and between inter-organisational relationships and supply chain performance.

Practical/managerial implications: Supply management professionals in the manufacturing sector may use the results of this study as a tool in the diagnoses of supply chain performancerelated problems, by checking for the proper alignment of the factors considered in the research.

Contribution/value-add: These results validate the importance of effective supply chain management practices in shaping supply chain performance in manufacturing environments. By monitoring and responding positively to the changes in key resources within manufacturing supply chains, managers can be able to improve the sharing of information and develop better relationships among trading partners, leading to superior performance of the entire supply chain.

\section{Introduction}

Similar to most developing and developed economies, manufacturing firms in South Africa remain at the epicentre of economic growth. By 2016, the manufacturing sector was contributing nearly $14 \%$ of the country's gross domestic product (GDP) and employed nearly 2 million people (Trading Economics 2016), making it one of the important pillars of the economy. Key industries in the manufacturing sector in South Africa include agri-processing, chemicals, automobiles, metals and textiles (Statistics South Africa 2016a). Yet, despite its importance, the manufacturing sector remains under continuous threat from various factors, such as the weakening of the local currency, increasing global competition, a volatile global economy, shortages of critical skills in South Africa and a host of political, social, technological as well as ecological factors (Pillay 2015). As a result, the sector continues to grow at a slower pace compared with other sectors of the economy, making South Africa a less attractive destination for investment. The weakening of the South African rand against major world currencies has been detrimental to the manufacturing sector in that it has made the importation of raw materials more expensive (Statistics South Africa 2016b). Increasing global competition has resulted in buyers preferring products which are less costly, such as those that are made in China (Edwards \& Jenkins 2014a). The slowing down of the global economy has had negative implications on the South African manufacturing sector in that 
there are fewer international buyers for South African products (Engineering News 2013). Also, the shortage of critical skills has had the effect of lowering production capacities of various industries within the manufacturing sector (Reddy 2016). Vast technological changes taking place all over the world have had an overwhelming cost implication for the manufacturing sector, as more funds are needed to invest in these new technologies (Industrial Development Corporation 2016). Unless measures to address these threats are generated and implemented, the South African manufacturing sector will continue to contract, with obvious negative economic consequences.

In order to remain viable, manufacturing firms have to develop and implement other emerging business strategies that have been proven to be effective when dealing with both internal and external threats (Edwards \& Jenkins 2014b). There are various business strategies available for selection by manufacturing firms as they seek to overcome the challenges they encounter in their operations. Among other things, these strategies include the adoption and optimisation of supply chain management practices (Ali \& Boylan 2012; Wieczorek 2012). In their quest to improve their competitiveness, manufacturing firms have adopted supply chain management practices such as quality management, e-procurement, technology adoption, risk management, supplier and customer relationship management, information sharing and collaboration, among others (Flynn, Huo \& Zhao 2010; Schoenherr \& Swink 2012; Wong, Boon-Itt \& Wong 2011; Zhao et al. 2011). Often, the adoption of such practices has proved to be a valuable way of securing competitive advantage and improving the firm's performance (Prajogo \& Olhager 2012). This has led to the adoption of the widely acclaimed view that competition is no longer between firms but among supply chains (Antin 2013; Dominiguez, Framinan \& Cannela 2014; Li et al. 2006). Supply chain management is defined as the integration of key business processes from end-users through original suppliers that provide products, services and information that add value for customers and other stakeholders (Lambert, Cooper \& Pagh 1998:1; Stadtler, Kilger \& Meyr 2015:3). The objectives of supply chain management include cost reduction, improving customer satisfaction, improvement of efficiency and effectiveness, and increasing competitiveness (Cao \& Zhang 2011; Cooper \& Ellram 1993; Cooper, Lambert \& Pagh 1997; Ding, Guo \& Liu 2011; Giunipero \& Brand 1996; Weber et al. 2010). Other objectives of supply chain management include the reduction of inventory levels and associated costs, increasing profits, improving cooperation and increasing overall supply chain performance (Christopher \& Jüttner 2000; Droge, Jayaram \& Vickery 2004; Droge, Vickery \& Jacobs 2012; Koçoğlu et al. 2011).

It has been noted by some authors (Cai et al. 2009; Du et al. 2012; Koçoğlu et al. 2011; Li \& Lin 2006) that challenges faced within supply chains typically stem from the interaction between the dynamic nature of these supply chains, information exchanges and relationships between supply chain partners. The dynamic nature of a supply chain refers to variations regarding any component factor, such as suppliers, customers, products, technology, among others, within a particular supply chain (Leuschner, Rogers \& Charvet 2013:34). Moreover, despite an increase in the awareness of the importance of supply chain management, performance of most manufacturing supply chains in South Africa remains unsatisfactory and realisation of supply chain management objectives remains limited, owing to the existence of various constraints (KPMG 2013; Nel 2017; Outlook 2015). Such constraints include inter alia high overhead costs, low productivity, financially distressed suppliers, weakening of the South African rand against major currencies, long lead times, deteriorating road infrastructure, unfavourable regulations and market uncertainty with long reaction times (Ambe \& Badenhorst-Weiss 2013). This situation is undesirable, given that the ultimate goal of all supply chain management activities is the improvement of overall supply chain performance (Gokhan \& Needy 2010; Lotfi et al. 2013). Hence, the aim of this study is to examine the relationship between supply chain dynamism, information sharing, interorganisational relationships and supply chain performance in manufacturing firms in South Africa. The results of this study can be used to improve the position of manufacturing firms in South Africa in light of the existing constraints and threats.

Available literature on supply chain management practices among South African manufacturers sets in motion the need to conduct more research in the sector. A literature search conducted within the ambit of the present study identified a number of previous studies (Ambe \& Badenhorst-Weiss 2013; Chiromo, Nel \& Sebele 2015; Naude 2013; Naude \& Badenhorst-Weiss 2011) that were based on the manufacturing sector in South Africa. However, whilst these studies focused on uncovering the challenges in various manufacturing industries, they disregarded the relationships considered in the current study. Also, other available studies based in South Africa (Cheng 2011; Hall \& Saygin 2012; Lee, Swink \& Pandejpong 2011; Qrunfleh \& Tarafdar 2014) only considered some of the individual constructs without testing the overall conceptual framework that is under consideration in this article. The current study is intended to address these gaps. Information emerging from this article may be used by supply management professionals in the manufacturing sector in South Africa to improve the performance of their supply chains by manipulating the dynamism, information sharing and inter-organisational relationships within their supply chains.

This article is structured as follows: the next section reviews the literature on the constructs used in this study. Thereafter, a conceptual framework is proposed, followed by the formulation of hypotheses. The research methodology is then outlined, followed by the results of the study. This is followed by the discussion, limitations and implications for future research and the conclusions and managerial implications, which is the final section of the article. 


\section{Literature review}

This section briefly discusses the four constructs under consideration, namely supply chain dynamism, information sharing, inter-organisational relationships and supply chain performance.

\section{Supply chain dynamism}

Supply chain dynamism is defined as the pace of change in products, technologies, manufacturing, orders and demand and supply for products in the supply chain (Green, Whitten \& Inman 2012:1008; Zhou \& Benton 2007:1348). Supply chain dynamism can be measured by (1) the degree of new products accounting for a high portion of total revenue; (2) the degree of the innovation frequency for products and service; and (3) the innovation rate of operating processes (Lee, Seo \& Dinwoodie 2016; Zhou \& Benton 2007). Owing to the dynamism and complexity of the modern business environment, firms require leverage and their innovativeness to respond to such unpredictable changes (Golgeci \& Ponomarov 2013). This leverage could be with regard to advantages such as the ability to access raw materials without interruptions, low-cost advantages, possession of greater market share, having a high degree of brand loyalty and greater access to capital (Khajavi, Partanen \& Holmström 2014; Merlino \& Sproge 2017; Singh \& Acharya 2013; Wang et al. 2015). In view of this, Lee et al. (2016) posit that under high levels of supply chain dynamism, diffusion and sharing of recent integrated information systems and proper knowledge and information within and between firms should be enhanced. In addition, the role of external forces that include political, economic, social, legal and ecological factors in stimulating the triggers for supply chain dynamism cannot be underestimated (Boute et al. 2012; Simangunsong, Hendry \& Stevenson 2012). Such changes in the external environment can trigger the adaptation of the manufacturing and production processes of manufacturers as well as other processes, such as delivery and forecasting (Lee et al. 2016). Zailani and Rajagopal (2005) and Yu et al. (2013) further emphasise the importance of the firm's ability to rapidly recognise and read market signals so that they can react accordingly with innovative products, services and processes as well as the product's short life cycle. Thus, it is imperative for businesses in dynamic manufacturing supply chains in South Africa to continuously reengineer their processes and products to be able to respond according to changes in the environment.

\section{Information sharing}

There are three types of flows moving upstream and downstream in any supply chain, which are products, funds and information (Ganesh, Raghunathan \& Rajendran 2014). In supply chain management, the flow (exchange) of information is crucial and is well documented in literature (Simchi-Levi \& Kaminsky 2008; Wu, Chuang \& Hsu 2014). Information sharing is defined as the extent to which one party in the chain communicates critical and proprietary information to another party in the chain (Fiala 2005:419;
Ha, Tong \& Zhang 2011:566; Özer, Zheng \& Chen 2011:1111). Merschmann and Thonemann (2011) opine that supply chain partners who exchange information regularly are able to work as a single unit as they can better understand the needs of the final customer and hence can respond much faster to market changes. More intense information sharing establishes high levels of cooperative behaviours among supply chain partners, which leads to strengthened long-term relationships between them (Eckerd \& Hill 2012; Klein, Rai \& Straub 2007). In addition, information sharing facilitates quicker responses by suppliers to consumer demands as they become better positioned to appropriately schedule the replenishment of the inventory (Chen \& Lee 2009).

According to some scholars (Ganesh et al. 2014; Li, Ye \& Sheu 2014), information sharing often enhances the accuracy of demand forecasts, which facilitates improved price structures, streamlined production scheduling and superior management of consumer demand. Still, information sharing synchronises supply chain processes to improve material flows, which lessens inventory costs (Sezen 2008). Information sharing also stimulates efficient supply chain integration by empowering firms to realise more reliable deliveries and reduce the time to market their products (Choi, Lee \& Yoo 2010; Özer, Zheng \& Ren 2014). To this end, Min and Yu (2008) consider information sharing as an important approach to increasing organisational efficiency and performance. Since some manufacturing firms in South Africa are still in their growth stage, the exchange of information with other stakeholders is critical for sustained advancement of business as paybacks are realised (Dewa, Matope \& Van Der Merwe 2014). Thus, information sharing between business partners remains a major building block that characterises solid supply chain operations (Wu et al. 2014).

\section{Inter-organisational relationships}

An inter-organisational relationship refers to the degree of trust, commitment and shared vision between supplier partners (Varoutsa \& Scapens 2015:68). Without the foundation of effective inter-organisational relationships, most efforts to manage the flow of information or materials across the supply chain are likely to be ineffective (Martin 2009; Palanski, Kahai \& Yammarino 2011; Ziakas \& Costa 2010). One of the most significant paradigmatic shifts adopted in modern businesses is that individual firms no longer compete as exclusively autonomous entities but rather as supply chains, that is, in synergy with other players in the market (Chen et al. 2011; Human \& Naudé 2009). Firms compete and win based on the capabilities they can assemble across their supply networks (Al-Laham, Amburgey \& Baden-Fuller 2010; Hess \& Rothaermel 2011; Laan et al. 2011; Sorrentino \& Garraffo 2012). This denotes a need for firms to link up with others within their supply chains and complement each other to meet their mutually shared goals and values (Chen, Lin \& Yen 2014; Matanda \& Freeman 2009).

The development of mutually shared goals and values provides the basis for reciprocal trust and commitment 
building in project teams (Eriksson \& Laan 2007; Lau \& Rowlinson 2009). These can be realised through the establishment of strategic management relationships that explicitly demonstrate mutually shared goals and objectives (Costa \& Bijlsma-Frankema 2007; Mayer, Davis \& Schroorman 2007). The use of charters and agreements which explicitly prescribe mutually shared goals and values can also create an environment conducive to the development of trust and commitment between supply chain partners (Manu Ankrah, Chinyio \& Proverbs 2015). A key element for emerging economies such as South Africa is that the establishment of inter-organisational interactions could be an important source of innovation as novel ideas are exchanged through organisational learning (Rensburg, Nieuwenhuizen \& De Bruyn 2014). This exchange of novel ideas could lead to new solutions which will be applied to counter any prevailing challenges, thereby providing a further boost for the growth of the manufacturing sector in South Africa.

\section{Supply chain performance}

Supply chain performance is defined as the ability of the supply chain to (1) deliver quality products and services in precise quantities and at precise times and (2) minimise total cost of products and services to the ultimate customers of the supply chain (Bode et al. 2011:833; Green et al. 2005:276; Hult, Craighead \& Ketchen 2010:435). In most firms, the responsibility for firm performance is placed on capabilities of management. However, in recent times, it has been noted that organisational success depends upon the performance of the supply chains in which the firm functions as a partner (Abu Bakar et al. 2010; Hoejmose, Roehrich \& Grosvold 2014; Jiang, Stephan \& Naudé 2011). An efficient supply chain can lead to a variety of paybacks that include reduced costs, greater market share and sales, and sustainable relationships with customers, among others (Brandenburg et al. 2014; Seuring 2013; Seuring \& Muller 2008). Green et al. (2012) underscore that the evaluation of supply chain performance can lead to improvements in the overall performance of the organisation. In a supply chain, efficiency is the potential outcome of the integration of the performance of all members (Alexiev, Volberda \& Van den Bosch 2016; Sodhi, Son \& Tang 2012). This makes the task of managing the overall supply chain efficiency a challenging task, as the individual performances of all players have to be taken into consideration (Flynn et al. 2010). Improving supply chain performance has become one of the critical issues in sustaining competitive advantages for companies (Cai et al. 2009; Estampe et al. 2013; Trkman, Budler \& Groznik 2015).

\section{Conceptual framework and hypotheses development}

Based on the literature reviewed, the conceptual framework illustrated in Figure 1 was developed. In the framework, supply chain dynamism is the predictor variable, information sharing and inter-organisational relationships are mediating variables and supply chain performance is the outcome variable.

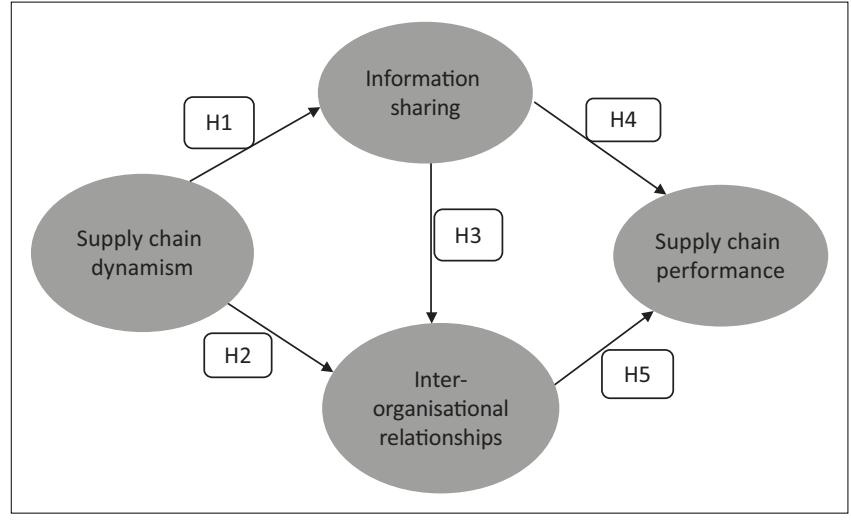

FIGURE 1: Conceptual framework.

In this article, five hypotheses $\left(\mathrm{H}_{1}\right.$ to $\left.\mathrm{H}_{5}\right)$ were formulated in line with the proposed relationships. These hypotheses were derived from previous literature as discussed below.

\section{Supply chain dynamism and information sharing}

Perceived uncertainty within the supply chain results from the failure of individual managers to predict changes in that supply chain (Lotfi et al. 2013). These changes may result from variations in technology, regulation, income volatility, products and markets, which lead to a lack of the information needed to identify data for decision-making (Du et al. 2012). Increasing volatility of customer demands may compel a firm to share more information with its supply chain partners in order to respond to changing customer needs (Qrunfleh \& Tarafdar 2014; Swafford, Ghosh \& Murthy 2008). Ding et al. (2011) observe that an improvement in supply chain dynamism leads to an increased capacity to process information, which in turn leads to improved firm performance. In support, Pandey, Garg and Shankar (2010) opine that higher supply chain dynamism triggers more effective information needs between supply chain partners. Likewise, Fawcett, Magnan and McCarter (2008) indicate that when there are upsurges in supply chain dynamism, firms are forced to better leverage their information sharing mechanisms in order to capture dynamic information in their supply chains. For instance, when the number of suppliers engaged by a firm increases, so does the combined amount of information exchanged between that firm and the suppliers. Yet, according to Lofti et al. (2013), the inability to deal with variations of orders and inventory levels within supply chains can lead to the sharing of distorted information between buyers and suppliers. This leads to the following hypothesis:

H1: There is a significant positive relationship between supply chain dynamism and information sharing.

\section{Supply chain dynamism and inter-organisational relationships}

In fast changing and turbulent supply chains, it is not practicable for single firms to acquire all the resources needed to effectively serve their customers on their own (Blome, Schoenherr \& Rexhausen 2013; Stevenson \& Spring 2007). The firm has to rely on other players in the supply 
chain to provide those resources that it cannot mobilise by itself, which calls for building relationships (Lai et al. 2011). Skipper and Hanna (2009) and Vilko, Ritala and Edelmann (2014) underscore that as supply chain uncertainty increases, the need for more intensive inter-organisational expertise intensifies, as more diverse skills and knowledge become necessary to generate solutions and remain competitive. It is also argued that the more rapid the changes in products, technology and demand of products in a market, the greater the potential for issues of power, trust and conflict between supply chain partners. Fawcett et al. (2008) and Ramanathan (2014) further argue that the closer the interdependency between supply chain partners, the greater the harm (both intentional and accidental) one partner can inflict upon the other. For example, the potential for conflict between competing firms increases as customers demand lower prices for commodities (Clivillé \& Berrah 2012; He \& Baruch 2010). Conversely, relationships formed between partners in a more stable supply chain are bound to last longer because of the existence of mutual trust and the decrease in uncertainty (Lai et al. 2011). Based on these assertions, the following hypothesis is put forward:

H2: There is a significant positive relationship between supply chain dynamism and inter-organisational relationships.

\section{Information sharing and inter-organisational relationships}

Information sharing is considered an essential activity to enhancing inter-organisational efficiency and performance (Bachmann \& Inkpen 2011; Youn, Yang, Hong \& Park 2013). Partnering firms share critical and proprietary information to sustain and support their partnership relationships (Vijayasarathy 2010). Typical information shared includes production plans, demand forecasts, inventory levels and supply capacity, which are the benefits that can be gained by both downstream operators and upstream suppliers (Ding et al. 2011). Attempts to manage the flow of either information or material across a supply chain is likely to be unsuccessful without effective relationships between the firms in that supply chain (Rajaguru \& Matanda 2009; Zhang \& Lu 2011). Proper and timely information sharing among supply chain members enables partners to effectively manage their relationships in a better way (Mansoori, Jamshidinavid \& Hashemi 2014). Furthermore, meaningful inter-organisational relationships based on trust, commitment and shared vision are necessary to encourage information sharing and to prevail against the fear of information disclosure as well as the loss of power over competitors (Chandra, Grabis \& Tumanyan 2007; Elmsalmi \& Hachicha 2014). Improving information exchange between firms provides greater visibility and opportunities to respond to change (Mishra \& Sharma 2014; Stevenson \& Spring 2009). Information sharing is also a significant constituent component in the integration of partners within a supply chain (Soosay, Hyland \& Ferrer 2008; Yilmaz, Çemberci \& Uca 2016). Hence, information sharing between supply chain partners has been detected as the central component of effective supply chain management. The following hypothesis is therefore proposed:
H3: There is a significant positive relationship between information sharing and inter-organisational relationships.

\section{Information sharing and supply chain performance}

Information sharing between supply chain partners has been considered a useful strategy to improve supply chain performance (Forslund \& Jonsson 2007; Jonsson \& Mattsson 2013; Simatupang \& Sridharan 2002). Information sharing can reduce the risk brought about by irregular and incomplete information, cut down lead times in production and increase total supply chain profits (Flynn et al. 2010). Through the exchange of information between supply chain partners, customer value may be increased and the total costs incurred when operating in a supply chain reduced significantly as the information exchanged can be used to improve products and identify areas where cost-cutting measures may be applied (Lin, Huang \& Lin 2002; Nyaga, Whipple \& Lynch 2010). There are several examples to demonstrate the positive influence of information sharing on supply chain performance. For instance, information sharing facilitates better decisions on ordering, capacity allocation, production and material planning through increased visibility of demand, supply and inventory (Iyer, Germain \& Claycomb 2009; Madlberger \& Roztocki 2010). Some studies (Chavez et al. 2015; Forslund \& Jonsson 2007; Soosay et al. 2008) further suggest that information sharing leads to improved business performance through its role as the driver of competitiveness and supply chain effectiveness. In this regard, Iyer et al. (2009) and Leuschner et al. (2013) submit that information sharing has a positive impact on supply chain performance, and that this provides competitive advantages for the firms. Eventually, superior customer value for the firm's long-term survival and success within the context of the supply chain are created (Lai, Wong \& Cheng 2010; Lun et al. 2016; Zhao, Xie \& Zhang 2002). Based on this theoretical evidence, the following hypothesis is postulated:

H4: There is a significant positive relationship between information sharing and supply chain performance.

\section{Inter-organisational relationships and supply chain performance}

Inter-organisational relationships are a business tool that lead to the improved interfacing among organisations that share a common set of goals and measures (Ramanathan 2014). This is done as a process for parties to mutually search for solutions and as a relationship in which supply chain partners develop a long-term cooperative effort (McCarthy \& Golicic 2002; Prajogo \& Olhager 2012). Common to these two descriptions is a long-lasting relationship between supply chain partners that work together. Focusing cooperative energies on strategic sources of disruption between supply chain partners can result in enhanced performance for the supply chain (Yang \& Lai 2012). Whipple and Russell (2007) and Patel, Pettitt and Wilson (2012) suggest that working collaboratively with each other will boost the success level of the supply chain. The level and depth of relationships determine the level of data shared, 
which in turn facilitates the planning and simplifies the flow of operations (Barrat 2004; Rajaguru \& Matanda 2013). Relationships among firms on the management of various supply chain activities is acknowledged to be a driver of competitive advantages over other supply chains (La Londe \& Masters 1994; Luzzini et al. 2015; Mentzer, Foggin \& Golicic 2000). Ireland and Bruce (2000) and Chen et al. (2014) suggest that healthy relationships are a critical business function that can contribute to the disruption of activities at the point between supply chain partners where a product is planned, ordered and restocked. As such, inter-organisational relationships provide a substantial opportunity for improved supply chain performance and should be viewed as a priority for firms adopting a supply chain management approach (Gallear, Ghobadian \& Chen 2012). This leads to the following hypothesis:

H5: There is a significant positive relationship between interorganisational relationships and supply chain performance.

\section{Research methodology}

This section outlines the research design, sampling design, instrumentation and data collection techniques, and data analysis employed in the study.

\section{Research design}

A quantitative research approach was espoused since the study was testing relationships between various constructs (Creswell 2013). A cross-sectional survey design was adopted to allow data to be collected from the required large sample in the same period of time. In addition, a survey design is less costly than other designs and is more likely to produce honest responses owing to anonymity of respondents, and is less likely to be influenced by the characteristics of the researcher (Behrend et al. 2011).

\section{Sampling design}

The sample in this study was composed of 340 supply management professionals from manufacturing firms based in the Gauteng Province of South Africa. Supply management professionals are individuals who are qualified to work in any area related to supply chain management, such as inter alia procurement, logistics and transportation, warehousing demand planning, customer relationship management, third and fourth party logistics services and manufacturing operations (Lambert 2014). Manufacturing is that branch of trade based on the fabrication, processing or preparation of products from raw materials and commodities. In South Africa, the manufacturing sector is dominated by six major industries, namely agri-processing, automobiles, chemicals, ICT and electronics, metals and textiles, clothing and footwear (Brand South Africa 2017). Respondents were selected based on the non-probability approach using the purposive sampling technique, to ensure that only those that had information relevant to the study were included in the sample. To be included in the sample study, individuals had to meet two criteria. Firstly, one had to have at least either a college/university or a professional qualification in a discipline related to logistics/supply chain management. Secondly, the individual had to be currently occupying a position falling within logistics/supply chain management. Contacts established within the human resource departments of the participating firms assisted with the lists of such individuals.

In selecting the departments, small-scale and micro enterprises were excluded from the study as they were unlikely to have experienced supply chain dynamism, information sharing and inter-organisational relationships to the extent that these issues were experienced by their larger counterparts. Accordingly, only medium (employing between 51 and 200 people) and large-scale (employing more than 200 people) (South African Government Gazette 2003:8) manufacturing enterprises were included in the study. An Internet search was conducted to identify medium and large-scale manufacturing firms based in Gauteng Province. The search words used were 'Manufacturing companies/factories/firms' in Gauteng Province. This search led to webpages such as BizCommunity, Yellow Pages South Africa and Industrial Buyer, which contained the information about various manufacturing enterprises and their contact details. Out of a total of 84 firms that were contacted telephonically and through email, 37 did not respond and 16 turned down the request for research. This left a total of 31 firms from which permission to collect data was granted.

The profile of participating firms (Table 2) shows that the largest number had been in operation for periods ranging between 6 and 10 years $(35.5 \% ; n=11)$. In addition, the majority (54.8\%: $n=2$ ) of the firms were medium-scale enterprises and the remaining $(45.2 \% ; n=14)$ were largescale enterprises. In terms of industry, the largest number of participating firms were from the agri-processing industry $(41.9 \% ; n=13)$.

\section{Instrumentation and data collection techniques}

Measurement scales were operationalised from previous studies. Supply chain dynamism was measured using four questions adapted from Zhou and Benton (2007). Information sharing was measured using six questions adapted from Li et al. (2006). Inter-organisational relationships were measured using five questions adapted from $\mathrm{Li}$ and $\mathrm{Lin}$ (2006), while supply chain performance was measured using five questions adapted from Green et al. (2012). Response options were configured using 5-point Likert-type scales anchored by $1=$ Strongly disagree and $5=$ Strongly agree. The measurement scales used in the study were chosen because they are the original scales, are already validated and had been used in several other previous studies, which made them more credible sources when compared to more recent ones that are based on the original scales. A list of items used in the measurement scales is provided in Appendix 1.

A pre-test of the questionnaire was conducted using a conveniently selected sample of 15 supply management professionals to ascertain the content validity of the 
measurement instrument. Feedback obtained from the pre-test sample was used to improve the content validity by modifying the questionnaire in terms of the wording of questions, their presentation and technical layout. Respondents that participated in the pre-test were excluded from the main survey. The actual collection of data took place between October 2015 and March 2016. In administering the survey, the drop and collect method was used in which respondents were given three weeks to complete the questionnaire. Out of the 600 questionnaires initially distributed, 363 were returned. However, 23 questionnaires contained errors and were accordingly discarded, resulting in 340 questionnaires usable for the final data analysis and a filtered response rate of $57 \%$, which, according to Fincham (2008), is acceptable in quantitative studies.

\section{Data analysis}

After screening the questionnaires, data were entered in a Microsoft Excel document for coding. Thereafter, the Excel document was entered in a Statistical Package for the Social Sciences (SPSS version 23.0) statistical tool for analysing descriptive statistics and Cronbach's alpha values for the constructs. For the assessment of the psychometric properties of the measurement scales and the testing of hypotheses, the Analysis of Moment Structures (AMOS 23) software was used.

\section{Ethical considerations}

Ethical clearance for the study was obtained from the Higher degrees Committee at Vaal University of Technology, Faculty of Management Sciences, reference: HDC/310316/02. Informed consent was obtained from all participants, and participation was on a voluntary basis. Also, anonymity of respondents was ensured so as to protect them from victimisation.

\section{Research results}

The research results section discusses the demographic profile of respondents, accuracy analysis statistics and the results of the hypotheses tests.

\section{Demographic profile of respondents}

The demographic details of the 340 respondents who completed the survey questionnaire is provided in Table 1.

The profile of the 31 firms that participated in the survey is presented in Table 2.

\section{Accuracy analysis statistics}

In accordance with the structural equation modelling (SEM) approach suggested by Anderson and Gerbing (1988), a confirmatory factor analysis (CFA) was conducted first to determine the psychometric properties of the scale (validity, reliability and model fit), followed by the testing of hypotheses through path analysis. The results of the CFA are reported in Table 3.
TABLE 1: Demographic profile of respondents.

\begin{tabular}{llcc}
\hline Demographic variable & Categories & Frequency $(\boldsymbol{n})$ & Percentage (\%) \\
\hline Gender & Male & 211 & 62.0 \\
& Female & 129 & 38.0 \\
Age groups & $18-35$ years & 124 & 36.5 \\
& $36-50$ years & 111 & 32.6 \\
& 51 years+ & 105 & 30.8 \\
Educational & Certificate & 98 & 28.8 \\
qualifications $\dagger$ & Diploma & 145 & 40.9 \\
& Degree & 42 & 12.4 \\
& Postgraduate & 14 & 4.11 \\
& Other (e.g. professional) & 41 & 13.9 \\
Years of experience & $<10$ years & 178 & 52.4 \\
& 11-20 years & 101 & 29.7 \\
& 21 years + & 61 & 17.9 \\
\hline
\end{tabular}

$\dagger$, only those respondents in possession of a post-matric qualification in logistics/supply chain management were included in the survey.

TABLE 2: Profile of participating firms.

\begin{tabular}{llcc}
\hline Demographic variable & Categories & Frequency $(\boldsymbol{n})$ & Percentage (\%) \\
\hline Years in operation & $\leq 5$ years & 7 & 22.50 \\
& 6-10 years & 11 & 35.50 \\
& $11-15$ years & 8 & 25.80 \\
& $16-20$ years & 4 & 12.90 \\
& $21+$ years & 1 & 3.23 \\
Number of employees†ं & 51-200 & 17 & 54.80 \\
& 201+ & 14 & 45.20 \\
Industry & Agri-processing & 13 & 41.90 \\
& Chemicals & 3 & 9.70 \\
& Metals & 8 & 25.80 \\
& Textiles & 3 & 9.70 \\
& Other (e.g. automobiles & 4 & 12.90 \\
& and electronics) & & \\
\hline
\end{tabular}

$\dagger$, only medium and large-scale enterprises were included in the firm.

Table 3 indicates that the item-to-total values ranged from 0.412 to 0.824 . These values were above the recommended minimum threshold value of 0.3 recommended by Dunn, Seaker and Waller (1994) and Gligor, Holcomb and Stank (2013). Cronbach's alpha values ranged from 0.782 to 0.873 , which exceeded the recommended minimum threshold of 0.7 (Bonett \& Wright 2015; Gliem \& Gliem 2003; Nunnally \& Bernstein 1994) and thus satisfies the reliability of the research measures. The item-total correlations and the Cronbach's coefficient alpha are complemented by the composite reliability values, which met the 0.7 minimum acceptable thresholds. Therefore, all four measurement scales were internally consistent.

Convergent validity was ascertained by calculating the average variance extracted (AVE). As suggested by Hair et al. (2010), AVE values greater than 0.50 indicate that the convergent validity of the construct is acceptable. As revealed in Table 3, AVE values ranged between 0.523 and 0.718 , which confirms the adequacy of convergent validity among the constructs. Another measure of convergent validity involves verifying whether factor loadings are greater than 0.5 (Kline 2010). Factor loadings for the four constructs ranged between 0.515 and 0.718 , which supports that convergent validity was satisfactory in this study. Discriminant validity was assessed through the use of inter-construct correlations. According to Clark and Watson (1995), correlation coefficients less than 1.0 
TABLE 3: Accuracy analysis measures.

\begin{tabular}{|c|c|c|c|c|c|c|c|}
\hline Research construct & Item coding & $\begin{array}{l}\text { Cronbach's test } \\
\text { Item-total correlation }\end{array}$ & $\begin{array}{c}\text { Cronbach's alpha } \\
\text { value }(\alpha)\end{array}$ & $\begin{array}{c}\text { Composite reliability } \\
\text { value (CR) }\end{array}$ & $\begin{array}{l}\text { Average variance } \\
\text { extracted (AVE) }\end{array}$ & $\begin{array}{l}\text { Highest shared } \\
\text { variance (SV) }\end{array}$ & Factor loadings \\
\hline \multirow{4}{*}{$\begin{array}{l}\text { Supply chain } \\
\text { dynamism (SCD) }\end{array}$} & SCD 1 & 0.412 & 0.841 & 0.756 & 0.664 & 0.55 & 0.576 \\
\hline & $\mathrm{SCD} 2$ & 0.534 & & & & & 0.574 \\
\hline & SCD3 & 0.540 & & & & & 0.661 \\
\hline & SCD4 & 0.513 & & & & & 0.567 \\
\hline \multirow{4}{*}{$\begin{array}{l}\text { Information } \\
\text { sharing (IS) }\end{array}$} & IS 1 & 0.764 & 0.794 & 0.703 & 0.781 & 0.51 & 0.702 \\
\hline & IS 2 & 0.694 & & & & & 0.688 \\
\hline & IS 4 & 0.716 & & & & & 0.515 \\
\hline & IS 6 & 0.744 & & & & & 0.522 \\
\hline \multirow{5}{*}{$\begin{array}{l}\text { Supply chain } \\
\text { performance (SCP) }\end{array}$} & SCP1 & 0.761 & 0.873 & 0.824 & 0.760 & 0.50 & 0.608 \\
\hline & SCP 2 & 0.727 & & & & & 0.517 \\
\hline & SCP 3 & 0.790 & & & & & 0.617 \\
\hline & $\mathrm{SCP} 4$ & 0.632 & & & & & 0.523 \\
\hline & SCP5 & 0.821 & & & & & 0.711 \\
\hline \multirow{5}{*}{$\begin{array}{l}\text { Inter-organisational } \\
\text { relationships (IOR) }\end{array}$} & IOR 1 & 0.641 & 0.782 & 0.833 & 0.823 & 0.57 & 0.526 \\
\hline & IOR 2 & 0.749 & & & & & 0.624 \\
\hline & IOR 3 & 0.824 & & & & & 0.682 \\
\hline & IOR4 & 0.712 & & & & & 0.541 \\
\hline & IOR5 & 0.814 & & & & & 0.637 \\
\hline
\end{tabular}

TABLE 4: Correlations between constructs.

\begin{tabular}{lcccc}
\hline Construct & $\begin{array}{c}\text { Supply chain } \\
\text { dynamism (SCD) }\end{array}$ & $\begin{array}{c}\text { Information } \\
\text { sharing (IS) }\end{array}$ & $\begin{array}{c}\text { Inter-organisational } \\
\text { relationships (IOR) }\end{array}$ & $\begin{array}{c}\text { Supply chain } \\
\text { performance (SCP) }\end{array}$ \\
\hline SCD & 1.000 & $0.697^{*}$ & 0.519 & 0.703 \\
IS & $0.697^{*}$ & 1.000 & $0.638^{*}$ & 0.669 \\
IOR & 0.519 & $0.638^{*}$ & 1.000 & 0.622 \\
SCP & 0.703 & 0.669 & 0.622 & 1.000 \\
\hline
\end{tabular}

$*, p<0.05$.

TABLE 5: Model fit analysis.

\begin{tabular}{lccc}
\hline Fit index & Thresholds & $\begin{array}{c}\text { Results for } \\
\text { confirmatory factor } \\
\text { analysis (CFA) }\end{array}$ & $\begin{array}{c}\text { Results for } \\
\text { structural equation } \\
\text { modelling (SEM) }\end{array}$ \\
\hline Chi-square/ degrees of freedom & $\leq 3.00$ & 2.083 & 1.179 \\
CFI (comparative fit index) & $\geq 0.90$ & 0.975 & 0.980 \\
RMSEA (root mean square & $\leq 0.08$ & 0.053 & 0.042 \\
error of approximation) & $\geq 0.90$ & 0.995 & 0.951 \\
NFI (normed fit index) & $\geq 0.90$ & 0.949 & 0.944 \\
TLI (Tucker-Lewis Index) & $\geq 0.90$ & 0.978 & 0.962 \\
IFI (incremental fit index) & $\geq 0.90$ & 0.906 & 0.942 \\
GFI (goodness of fit) & $\geq 0.90$ & 0.924 & 0.916 \\
AGFI (adjusted goodness of fit) & & & \\
\hline
\end{tabular}

indicate that discriminant validity is satisfactory. The results of the correlation analysis are provided in Table 4 .

As reported in Table 4, the inter-construct correlation values for all paired latent variables ranged between 0.519 and 0.703 , which is well below the recommended maximum threshold value of 1.0. Hence, discriminant validity was deemed sufficient in this study.

\section{Model fit}

The results of the model fit analysis for both CFA and SEM are provided in Table 5 .

Table 5 indicates that the measurement model yielded a ratio of chi-square value to degree-of-freedom of 2.083, as well as CFI, RMSEA, NFI, TLI, IFI, GFI and AGFI of 0.975, $0.053,0.995,0.949,0.978,0.906$ and 0.924 , respectively,
TABLE 6: Results of hypotheses tests.

\begin{tabular}{lccl}
\hline Path coefficients & Hypothesis & $\begin{array}{c}\text { Beta } \\
\text { coefficients }\end{array}$ & Decision \\
\hline $\begin{array}{l}\text { Supply chain dynamism and } \\
\text { information sharing }\end{array}$ & $\mathrm{H}_{1}$ & $0.172 * * *$ & Accept hypothesis \\
$\begin{array}{l}\text { Supply chain dynamism and } \\
\text { inter-organisational relationships }\end{array}$ & $\mathrm{H}_{2}$ & $0.621 * * *$ & Accept hypothesis \\
$\begin{array}{l}\text { Information sharing and } \\
\text { inter-organisational relationships }\end{array}$ & $\mathrm{H}_{3}$ & $0.177 * * *$ & Accept hypothesis \\
$\begin{array}{l}\text { Information sharing and supply } \\
\text { chain performance }\end{array}$ & $\mathrm{H}_{4}$ & $0.772 * * *$ & Accept hypothesis \\
$\begin{array}{l}\text { Inter-organisational relationships } \\
\text { and supply chain performance }\end{array}$ & $\mathrm{H}_{5}$ & $0.868 * * *$ & Accept hypothesis \\
\hline $\begin{array}{l}\text { Note: } \chi^{2} \text { (df) }=1.179 ; \text { goodness of fit index (GFI) }=0.942 ; \text { adjusted goodness of fit index } \\
\text { (AGFI) }=0.916 ; \text { incremental fit index (IFI) }=0.962 ; \text { normed fit index (NFI) }=0.951 ; \text { comparative } \\
\text { fit index (CFI) }=0.980 ; \text { root mean square error of approximation (RMSEA) }=0.042 .\end{array}$ \\
$* * *, p<0.01$.
\end{tabular}

during the CFA procedure. All of these statistics satisfied the recommended thresholds, which depict an acceptable fit of the CFA measurement model to the sample data. Model fit analysis for the SEM phase of the study was conducted before testing the hypotheses. The resulting statistics showed that the ratio of chi-square over degree-of-freedom was 1.179. This value is less than the recommended threshold of less than 3.0, and confirms the model fit. In addition, CFI, RMSEA, NFI, TLI, IFI, GFI and AGFI values were 0.980, 0.042, 0.951, 0.944, 0.962, 0.942 and 0.916 , respectively, which satisfied the recommended thresholds (West, Taylor \& Wu 2012). By implication, the proposed conceptual framework converged well and could be a plausible representation of the underlying empirical data structure collected in the Gauteng Province of South Africa.

\section{Hypotheses tests}

As the model fit was acceptable (Table 5), the research hypotheses were subsequently tested through the path analysis approach. The results are provided in Table 6.

As indicated in Table 6, all five hypotheses were accepted, indicating that the proposed relationships between constructs were valid. The loadings of individual items on their 
respective constructs reported in Table 5 depict that the model converged well and could be a credible depiction of causal empirical data structures collected for this research. The individual results for the hypotheses tests are discussed in detail in the next section.

\section{Discussion}

The purpose of this study was to examine the relationship between supply chain dynamism, information sharing, interorganisational relationships and supply chain performance in the manufacturing sector in South Africa. A conceptual framework (Figure 1), which placed supply chain dynamism as the input variable (antecedent), information sharing and inter-organisational relationships as the mediating variables and supply chain performance as the outcome variable was put forward to illustrate the proposed relationships. Five null and alternative hypotheses were formulated to describe each section of the relationships between the variables.

A positive relationship was hypothesised between supply chain dynamism and information sharing $\left(\mathrm{Ha}_{1}\right)$, which was formulated from the objective that aimed to investigate the relationship between supply chain dynamism and information sharing. The positive and significant beta coefficients $(r=0.172 ; p<0.01)$ confirm the existence of a positive relationship between the two constructs. This relationship illustrates that there exists more pronounced information sharing whenever changes occur in the supply chain. The changes may be in terms of products, technology, manufacturing, orders and the demand and supply for products in the supply chain. As suggested by Gokhan and Needy (2010) and Gligor, Esmark and Holcomb (2015), supply chain dynamism can also be conceptualised in terms of the difference in the amount of information required and already possessed to perform a task within the supply chain. The supply chain becomes volatile whenever the possessed information is not adequate for task accomplishment, because it is either insufficient or excessive, resulting in information overload (Ben-Arieh \& Pollatscheck 2002; Durugbo 2015). A study conducted by Chan, Chung and Choy (2006) and Cardona-Valdés, Álvarez and Pacheco (2014) concluded that in light of the complexity of the interactions among supply chain partners, uncertainties at various points within the supply chain, which emanate from information-sharing disparities, were the main problems affecting firm performance. Gunasekaran, Lai and Cheng (2008) and Farahani et al. (2014) add that with increased information sharing and operational knowledge, firms can be more responsive to volatile demand resulting from frequent changes in competition, technology and regulation. By implication, the dynamism of manufacturing supply chains in South Africa could give firms an impetus to expedite and streamline the exchange of timely information with their supply chain partners. The positive outcomes associated with information sharing could then be realised.

Another positive relationship was hypothesised between supply chain dynamism and inter-organisational relationships
$\left(\mathrm{Ha}_{2}\right)$. This hypothesis was formulated in an attempt to determine whether or not supply chain dynamism has a relationship with inter-organisational relationships. This relationship was validated based on the strong positive and significant beta coefficients $(r=0.621 ; p<0.01)$ existing between the two constructs. That uncertainties within the supply chain can influence relationships between partners is a universally acknowledged fact (Deo \& Corbett 2010). For example, a malfunctioning production process at the supplier, late delivery or unacceptable quality of the delivered supplies may result in customer dissatisfaction. If these inconsistencies are not addressed, relationships between the underperforming supplier and the customer could be ruined. Variations in demand of the final product in the market can also trigger either the underproduction or overproduction of the product, resulting in financial losses across the supply chain (Lumineau \& Quélin 2012). If these challenges are not investigated and the root causes established, accusations and counter-accusations can dominate the supply chain as firms struggle to cope with the consequences of uncertainties in demand (Sánchez, Vélez \& Álvarez-Dardet 2013).

The study hypothesised that information sharing has a significant positive relationship with inter-organisational relationships $\left(\mathrm{Ha}_{3}\right)$ This relationship was validated because of the positive and significant beta coefficient $(r=0.177 ; p<0.01)$. As suggested in a previous research by Yu, Yan and Cheng (2001), information sharing is conceptualised as a combination of resources and systems both tangible and intangible from different supply chain partners working together. On the one hand, optimum information exchanges of critical and proprietary information is an enabling factor for meaningful relationships between supply chain partners (Li \& Lin 2006; Lofti et al. 2013). On the other hand, both misinformation as well as the withholding of critical information that should be shared between supply chain partners could adversely affect their relationships (Fawcett et al. 2007: Pandey et al. 2010). In essence, the benefits of information sharing within a supply chain far outweigh the costs. Costs include factors such as charges by customers or suppliers for providing theinformation, the capital invested in information systems, communication costs and administration costs (Flynn et al. 2010). However, these costs seem to be minimal when compared to the wide array of benefits such as increased productivity, firm efficiency, improved services, creating and strengthening social bonds, strategic agility and earlier time to market, all of which can significantly improve inter-organisational relationships (Li \& Gao 2011). Therefore, in order to survive and compete in today's integrated global economy, the manufacturing sector strongly needs to create, share and disseminate up-to-date and appropriate knowledge and information with their supply chain partners (Scholten \& Schilder 2015).

The fourth alternative hypothesis $\left(\mathrm{Ha}_{4}\right)$ suggests that there is a positive significant relationship between information sharing and supply chain performance. This relationship was validated based on the strong positive and significant beta coefficient $(r=0.772 ; p<0.01)$ existing between the two 
constructs. These results are parallel to those in a previous study by Zhao et al. (2002) and Wu et al. (2014), which concluded that information sharing impacts the supply chain performance in terms of both total cost and service level. Lin et al. (2002) further underscore that higher levels of information sharing are associated with lower total costs, between order fulfilment rates and shorter order cycle times. Timely exchanges of information can be vital for circumventing possible risks during times of turbulence. For instance, cautioning a manufacturer on the possibility of a decline in product demand can enable that manufacturer to take precautionary measures in production planning. Likewise, when accurate information is exchanged within a supply chain, each partner is able to make better informed decisions in all areas of the business, based on the provided information. Zhao et al. (2011) add that whenever information sharing is utilised efficiently, manufacturers can reduce inventory costs significantly $(10 \%-35 \%)$. In addition, information sharing within a supply chain is a source of great improvement in business connections, such as cross-docking, quick response (QR) as well as vendor managed inventory (VMI) (Jauhari 2009; Mourtzis 2011). This leads to improved overall performance of the supply chain (Qrunfleh \& Tarafdar 2014).

The fifth alternative hypothesis proposes the existence of a significant positive relationship between inter-organisational relationship and supply chain performance. This relationship was validated based on the strong positive and significant beta coefficients $(r=0.868 ; p<0.01)$ observed between the two constructs. These results are synchronous to previous studies (Schilke \& Cook 2013; Whipple \& Russel 2007), which concluded that the ability of firms to link and work together by sharing information, resources and risks has a stimulus effect on overall supply chain performance. International business literature (e.g. Arranz \& Fdez de Arroyabe 2012; Coombs, Bierly \& Gallagher 2012; Francis, Hasan \& Sun 2014) also acknowledges a number of positive outcomes for companies actively engaged in robust relationships with their supply chain partners, such as better return on investment, higher return on equity and higher success rates. A study by Lee (2013) concluded that business partners who trust each other will take care of each other during times of instability. For example, where robust relationships exist, supplier development is always considered a better option whenever the supplier is failing to meet customer expectations. This ensures that performance of both the supplying firm and its buying customer are maintained optimally.

\section{Limitations and implications for future research}

The results of the study are restricted to 31 manufacturing firms drawn from one province of South Africa, which undermines the generalisability of the results to manufacturing firms elsewhere. Future studies may be conducted by using data from other sectors of the economy such as retail, mining and agriculture, and using a larger number of manufacturing firms. Also, the geographic context of the study could be expanded to other regions of South Africa, apart from Gauteng Province. The study is further limited in that its results were not differentiated by the type of manufacturing industry segments. To address this, future studies could also be conducted in the different manufacturing industry segments such as agri-processing, automobiles, chemicals, electronics, metals and textiles. This will provide insights that are specific and customised to each particular industry. Furthermore, a comparative investigation of this study matter between or among countries that have different levels of development as well as cultures could provide additional insights and contribute new knowledge to the existing body of supply chain performance literature. Future research could also direct greater emphases to supply chain dynamism and its effects on other variables that mediate the relationship with supply chain performance. Such variables may include supply chain integration, supply chain agility, supply chain resilience and supplier selection, among others.

\section{Conclusion and managerial implications}

The study concludes that there is a significant positive relationship between supply chain dynamism and both information sharing and inter-organisational relationships in the manufacturing sector. It is further concluded that a significant positive relationship exists between interorganisational relationships and supply chain performance in the manufacturing sector. Still, the study concludes that a significant positive relationship exists between interorganisational relationships and supply chain performance in the manufacturing sector. The final conclusion is that inter-organisational relationships exert a greater influence on supply chain performance than does information sharing in the manufacturing sector.

This study provides useful theoretical insights for academic researchers. It provides a source of reference for future researchers on similar relationships within manufacturing environments. The results of this study on the outcomes of information sharing and inter-organisational relationships are not only in line with previous research (e.g. Deo \& Corbett 2010; Gunasekaran et al. 2008; Lofti et al. 2013; Zhao et al. 2011) but also provide information on how the interplay between supply chain dynamism and supply chain performance is significantly influenced by these mediating variables.

The study further provides useful implications for supply management professionals in improving supply chain performance to realise enhanced competitive advantage in the manufacturing sector. The conceptual framework used is an important tool in the diagnoses of problems related to supply chain performance in the manufacturing sector. Whenever there is an erosion of supply chain performance, it is necessary to check the alignment of the constructs considered in this study, as they exert a positive influence on each other. In addition, as the relationship between the various constructs were positive, enhancement of one also leads to the increase of the other constructs. Managers in the manufacturing sector 
should monitor and respond positively to the changes in key resources such as products, technology, demand and supply, and policies. This may enable them to improve the sharing of information and develop better relationships among trading partners, leading to superior performance of the entire supply chain. To improve both information sharing and interorganisational relationships, manufacturing firms should invest in information and communication technologies that improve their ability to manage information and knowledge across the supply chain. Supportive, trusting and long-term relationships between supply chain partners should be cultivated as this enables them to share risks and rewards. Better attitudes and practices among supply management professionals in manufacturing firms could be encouraged through training aimed at increasing their awareness of the importance of both information sharing and meaningful inter-organisational relationships. Willingness on the part of management in manufacturing firms to incorporate and coordinate the complex network of business relationships among supply chain members remains a key feature in improving supply chain performance. This stems from the realisation that for the individual firm to be successful, its supply chain must perform optimally. Paradigm shifts can thus be adopted in these areas, with implementation likely to result in improved supply chain performance.

\section{Acknowledgements}

This article is based on the Masters dissertation submitted to Vaal University of Technology, Faculty of Management Sciences. Supply chain dynamism, information sharing and interorganisational relationships and their effect on supply chain performance by Moipone Mashiloane available from http:/ / digiresearch.vut.ac.za/handle/10352/362.

\section{Competing interests}

The authors declare that they have no financial or personal relationships that may have inappropriately influenced them in writing this article.

\section{Authors' contributions}

M.W.M. conducted the literature review and collected the data. C.M. conducted the data analyses and wrote the results section. D.R.P. wrote the research methodology section and made language revisions to the article.

\section{References}

Abu Bakar, A.H., Lukman Hakim, I., Chong, S.C. \& Lin, B., 2010, 'Measuring supply chain performance among public hospital laboratories', International Journal of Productivity and Performance Management 59(1), 75-97. https://doi.org/ 10.1108/17410401011006121

Alexiev, A.S., Volberda, H.W. \& Van den Bosch, F.A., 2016, 'Inter-organisational collaboration and firm innovativeness: Unpacking the role of the organisational environment', Journal of Business Research 69(2), 974-984. https://doi.org/ 10.1016/j.jbusres.2015.09.002

Ali, M.M. \& Boylan, J.E., 2012, 'On the effect of non-optimal forecasting methods on supply chain downstream demand', IMA Journal of Management Mathematics 23, 81-98.

Al-Laham, A., Amburgey, T.L. \& Baden-Fuller, C., 2010, 'Who is my partner and how do we dance? Technological collaboration and patenting speed in US biotechnology', British Journal of Management 21, 789-807.
Ambe, I.M. \& Badenhorst - Wess, J.A., 2013, 'Challenges of locally manufactured vehicle supply chains in South Africa', Journal of Transport and Supply Chain Management 7(1), Art. \#100, 8 pages. https://doi.org/10.4102/jtscm.v7i1.100

Anderson, J.C. \& Gerbing, D.W., 1988, 'Structural equations modelling in practice: A review and recommended two-step approach', Psychological Bulletin 103(3), 411-423. https://doi.org/10.1037/0033-2909.103.3.411

Antin, D., 2013, The South African mining sector: An industry at a crossroads, HansSeidel Foundation, Johannesburg, Southern Africa.

Arranz, N. \& Fdez de Arroyabe, J.C., 2012, 'Effect of formal contracts, relational norms and trust on performance of joint research and development projects', British Journal of Management 23(4), 575-588. https://doi.org/10.1111/j.1467-8551. 2011.00791.x

Bachmann, R. \& Inkpen, A.C., 2011, 'Understanding institutional-based trust building processes in inter-organisational relationships', Organisation Studies 32(2), 281-301. https://doi.org/10.1177/0170840610397477

Barratt, M., 2004, 'Understanding the meaning of collaboration in the supply chain', Supply Chain Management: An International Journal 9(1), 30-42. https://doi. org/10.1108/13598540410517566

Behrend, T.S., Sharek, D.J., Meade, A.W. \& Wiebe, E.N., 2011, 'The viability of crowd sourcing for survey research', Behavior Research Methods 43(3), 800-813. https://doi.org/10.3758/s13428-011-0081-0

Ben-Arieh, D. \& Pollatscheck, M.A., 2002, 'Analysis of information flow in hierarchical organisations', International Journal of Production Research 40(15), 3561-3573. https://doi.org/10.1080/00207540210137611

Blome, C., Schoenherr, T. \& Rexhausen, D., 2013, 'Antecedents and enablers of supply chain agility and its effect on performance: A dynamic capabilities perspective', International Journal of Production Research 51(4), 1295-1318. https://doi.org/ 10.1080/00207543.2012.728011

Bode, C., Wagner, S., Petersen, K. \& Ellram, L., 2011, 'Understanding responses to supply chain disruptions: Insights from information processing and resource dependence perspectives', Academy of Management Journal 54(4), 833-856. dependence perspectives, Academy of Manag
https://doi.org/10.5465/AMJ.2011.64870145

Bonett, D.G. \& Wright, T.A., 2015, 'Cronbach's alpha reliability: Interval estimation, hypothesis testing, and sample size planning', Journal of Organisational Behavior 36(1), 3-15. https://doi.org/10.1002/job.1960

Boute, R.N., Dejonckheere, J., Disney, S.M. \& Van De Velde, W., 2012, 'Bullwhip in a multi-product production setting', Review of Business and Economic Literature 57(3), 354-380.

Brandenburg, M., Govindan, K., Sarkis, J. \& Seuring, S., 2014, 'Quantitative models for sustainable supply chain management: Developments and directions', European Journal of Operational Research 233(2), 299-312. https://doi.org/10.1016/j. ejor.2013.09.032

Brand South Africa, 2017, Manufacturing in South Africa, viewed 18 March 2018, from https://www.brandsouthafrica.com/investmentsimmigration/business/ economy/sectors/manufacturing-in-south-africa.

Cai, J., Liu, X., Xiao, Z. \& Liu, J., 2009, 'Improving supply chain performance management: A systematic approach to analysing iterative KPI accomplishment', Decision Support Systems 46(2), 512-521. https://doi.org/10.1016/j.dss.2008.09.004

Cao, M. \& Zhang, Q., 2011, 'Supply chain collaboration: Impact on collaborative advantage and firm performance', Journal of Operations Management 29(3), 163-180. https://doi.org/10.1016/j.jom.2010.12.008

Cardona-Valdés, Y., Álvarez, A. \& Pacheco, J., 2014, 'Metaheuristic procedure for a biobjective supply chain design problem with uncertainty', Transportation Research Part B: Methodological 60, 66-84. https://doi.org/10.1016/j.trb.2013.11.010

Chan, F.T., Chung, S.H. \& Choy, K.L., 2006, 'Optimisation of order fulfilment in distribution network problems', Journal of Intelligent Manufacturing 17(3), 307-319. https://doi.org/10.1007/s10845-005-0003-z

Chandra, C., Grabis, J. \& Tumanyan, A., 2007, 'Problem taxonomy: A step towards effective information sharing in supply chain management', International Journal of Production Research 45(11), 2507-2544. https://doi.org/10.1080/00207540 601020486

Chavez, R., Yu, W., Gimenez, C., Fynes, B. \& Wiengarten, F., 2015, 'Customer integration and operational performance: The mediating role of information quality', Decision Support Systems 80, 83-95. https://doi.org/10.1016/j.dss.2015.10.001

Chen, L. \& Lee, H.L., 2009, 'Information sharing and order variability control under a generalised demand model', Management Science 55(5), 781-797. https://doi. org $/ 10.1287 /$ mnsc. 1080.0983

Chen, J.V., Yen, D.C., Rajkumar, T.M. \& Tomochko, N.A., 2011, 'The antecedent factors on trust and commitment in supply chain relationships', Computer Standards \& Interfaces 33(3), 262-270. https://doi.org/10.1016/j.csi.2010.05.003

Chen, Y.H., Lin, T.P. \& Yen, D.C., 2014, 'How to facilitate inter-organisational knowledge sharing: The impact of trust', Information \& Management 51(5), 568-578. https:// doi.org/10.1016/j.im.2014.03.007

Cheng, J.H., 2011, 'Inter-organisational relationships and information sharing in supply chains', International Journal of Information Management 31(4), 374-384. https://doi.org/10.1016/j.ijinfomgt.2010.09.004

Chiromo, F., Nel, A. \& Sebele, T.O., 2015, 'Lean manufacturing challenges in a South African clothing company', International Association for Management of Technology, IAMOT 2015 Conference Proceeding, viewed 19 August 2017, from http://www.iamot2015.com/2015 proceedings/documents/P265.pdf

Choi, S.Y., Lee, H. \& Yoo, Y., 2010, 'The impact of information technology and transactive memory systems on knowledge sharing, application, and team performance: A field study', Management Information Systems Quarterly 34(4), 855-870. https://doi.org/10.2307/25750708 
Christopher, M. \& Jüttner, U., 2000, 'Developing strategic partnerships in the supply chain: A practitioner perspective', European Journal of Purchasing \& Supply chain: A practitioner perspective, European Journal of Purchasing \& Supply

Clark, L.A. \& Watson, D., 1995, 'Constructing validity: Basic issues in scale development' Psychological Assessment 7(3), 309-319. https://doi.org/10.1037/1040-3590. 7.3 .309

Clivillé, V. \& Berrah, L., 2012, 'Overall performance measurement in a supply chain Towards a supplier-prime manufacturer based model', Journal of Intelligent Manufacturing 23(6), 2459-2469. https://doi.org/10.1007/s10845-011-0512-x

Coombs, J.E., Bierly, P.E. \& Gallagher, E., 2012, 'The impact of different forms of IPO firm legitimacy on the choice of alliance governance structure', Journal of Management \& Organisation 18(4), 516-536.

Cooper, M.C. \& Ellram, L.M., 1993, 'Characteristics of supply chain management and the implications for purchasing and logistics strategy', The International Journal of Logistics Management 4(2), 13-24. https://doi.org/10.1108/09574099310804957

Cooper, M.C., Lambert, D.M. \& Pagh, J.D., 1997, 'Supply chain management: More than a new name for logistics', The International Journal of Logistics Management 8(1), 1-14. https://doi.org/10.1108/09574099710805556

Costa, A.C. \& Bijlsma-Frankema, K., 2007, 'Trust and control interrelations new perspectives on the trust-control nexus', Group \& Organisation Management perspectives on the trust-control nexus', Group \& Organisation
32(4), 392-406. https://doi.org/10.1177/1059601106293871

Creswell, J.W., 2013, Research design: Qualitative, quantitative and mixed methods approaches, Sage, New Jersey.

Deo, S. \& Corbett, C.J., 2010, 'Dynamic allocation of scarce resources under supply uncertainty', Social Science Research Network 1619408, viewed 01 November 2016, from https://pdfs.semanticscholar.org/550a/172c2f21ca68de54ed72b286 a78afd344f45.pd

Dewa, M.T., Matope, S. \& Van Der Merwe, A.F., 2014, 'An empirical analysis of operational disturbances and their impact on business performance in manufacturing firms: Case Tooling Industry South Africa', in Southern African Institute for Industrial Engineering 26 Proceedings, Muldersdrift, South Africa, July 14-16, 2014

Ding, H., Guo, B. \& Liu, Z., 2011, 'Information sharing and profit allotment based on supply chain cooperation', International Journal of Production Economics 133(1), 70-79. https://doi.org/10.1016/j.ijpe.2010.06.015

Dominiguez, R., Framinan, J.M. \& Cannella, S., 2014, 'Serial vs. divergent supply chain networks: A comparative analysis of the bullwhip effect', International Journal of Production Research 52(7), 2194-2210. https://doi.org/10.1080/00207543.2013. 860495

Droge, C., Jayaram, J. \& Vickery, S.K., 2004, 'The effects of internal versus external integration practices on time-based performance and overall firm performance', integration practices on time-based performance and overall firm performance',
Journal of Operations Management 22(6), 557-573. https://doi.org/10.1016/j. Journal of Operation

Droge, C., Vickery, S.K. \& Jacobs, M.A., 2012, 'Does supply chain integration mediate the relationships between product/process strategy and service performance? An empirical study', International Journal of Production Economics 137(2), 250-262. https://doi.org/10.1016/j.ijpe.2012.02.005

Du, T.C., Lai, V.S., Cheung, W. \& Cui, X., 2012, 'Willingness to share information in a supply chain: A partnership-data-process perspective', Information \& Management 49(2), 89-98. https://doi.org/10.1016/j.im.2011.10.003

Dunn, S.C., Seaker, R.F. \& Waller, M.A., 1994, 'Latent variables in business logistics research: Scale development and validation', Journal of Business Logistics 15, 145-145.

Durugbo, C., 2015, 'Modelling information for collaborative networks', Production Planning \& Control 26(1), 34-52. https://doi.org/10.1080/09537287.2013.847217

Eckerd, S. \& Hill, J.A., 2012, 'The buyer supplier social contract: Information sharing as a deterrent to unethical behaviors', International Journal of Operations \& Production Management 32(2), 238-255. https://doi.org/10.1108/01443571211208641

Edwards, L. \& Jenkins, R., 2014a, The competitive effects of China on the South African Manufacturing Sector, World Bank Group, viewed 18 March 2018, from http:// www.dpru.uct.ac.za/sites/default/files/image_tool/images/36/Publications/ Policy_Briefs/DPRU\%20PB\%2014-40.pdf

Edwards, L. \& Jenkins, R., 2014b, 'The margins of export competition: A new approach to evaluating the impact of 'China on South African exports to sub-Saharan Africa', Journal of Policy Modeling 36(1), S132-S150. https://doi.org/10.1016/j.jpolmod. Journal of Policy

Elmsalmi, M. \& Hachicha, W., 2014, 'Risk mitigation strategies according to the supply actors' objectives through MACTOR method' in 2014 International Conference on actors' objectives through MACTOR method', in 2014 International Conference on Advanced Logist

Engineering News, 2013, Manufacturing sector outlook and challenges, viewed 18 March 2018, from http://www.engineeringnews.co.za/article/manufacturingsector-outlook-and-challenges-2013-08-06/rep_id:4136

Eriksson, E.P. \& Laan, A., 2007, 'Procurement effects on trust and control in clientcontractor relationships' Engineering, Construction and Architectural Management 14(4), 387-399. https://doi.org/10.1108/09699980710760694

Estampe, D., Lamouri, S., Paris, J.L. \& Brahim-Djelloul, S., 2013, 'A framework for analysing supply chain performance evaluation models', International Journal of Production Economics 142(2), 247-258. https://doi.org/10.1016/j.ijpe.2010.11.024

Farahani, R.Z., Rezapour, S., Drezner, T. \& Fallah, S., 2014, 'Competitive supply chain network design: An overview of classifications, models, solution techniques and applications', Omega 45, 92-118. https://doi.org/10.1016/j.omega.2013.08.006

Fawcett, S.E., Magnan, G.M. \& McCarter, M.W., 2008, 'Benefits, barriers, and bridges to effective supply chain management', Supply Chain Management. An Internationa Journal 13(1), 35-48. https://doi.org/10.1108/13598540810850300
Fiala, P., 2005, 'Information sharing in supply chains', Omega 33(5), 419-423. https:// doi.org/10.1016/j.omega.2004.07.006

Fincham, J.E., 2008, 'Response rates and responsiveness for surveys, standards, and the journal', American Journal of Pharmaceutical Education 72(2), 43. https://doi. org/10.5688/aj720243

Flynn, B.B., Huo, B. \& Zhao, X., 2010, 'The impact of supply chain integration on performance: A contingency and configuration approach', Journal of Operation Management 28, 58-71. https://doi.org/10.1016/j.jom.2009.06.001

Forslund, H. \& Jonsson, P., 2007, 'The impact of forecast information quality on supply chain performance', International Journal of Operations \& Production Managemen 27(1), 90-107. https://doi.org/10.1108/01443570710714556

Francis, B.B., Hasan, I. \& Sun, X., 2014, 'Does relationship matter? The choice of financial advisors', Journal of Economics and Business 73, 22-47. https://doi. org/10.1016/j.jeconbus.2013.12.002

Gallear, D., Ghobadian, A. \& Chen, W., 2012, 'Corporate responsibility, supply chain partnership and performance: An empirical examination', International Journal of Production Economics 140(1), 83-91. https://doi.org/10.1016/j.ijpe.2012.01.016

Ganesh, M., Raghunathan, S. \& Rajendran, C., 2014, 'The value of information sharing in a multi-product, multi-level supply chain: Impact of product substitution, demand correlation, and partial information sharing', Decision Support Systems 58, 79-94. https://doi.org/10.1016/j.dss.2013.01.012

Giunipero, L.C. \& Brand, R.R., 1996, 'Purchasing's role in supply chain management' The International Journal of Logistics Management 7(1), 29-38. https://doi. org/10.1108/09574099610805412

Gliem, J.A. \& Gliem, R.R., 2003, 'Calculating, interpreting, and reporting Cronbach's alpha reliability coefficient for Likert-type scales', in Midwest Research-to-Practice Conference in Adult, Continuing and Community Education, Columbus, $\mathrm{OH}$ pp. 82-88.

Gligor, D.M., Esmark, C.L. \& Holcomb, M.C., 2015, 'Performance outcomes of supply chain agility: When should you be agile?', Journal of Operations Management 33 71-82. https://doi.org/10.1016/j.jom.2014.10.008

Gligor, D.M., Holcomb, M.C. \& Stank, T.P., 2013, 'A multidisciplinary approach to supply chain agility: Conceptualisation and scale development', Journal of Business Logistics 34(2), 94-108. https://doi.org/10.1111/jbl.12012

Gokhan, N.M. \& Needy, N., 2010, 'Development of a simultaneous design for supply chain process for the optimisation of the product design and supply chain configuration problem', Engineering Management Journal 22(4), 20-30. https:// doi.org/10.1080/10429247.2010.11431876

Golgeci, I. \& Ponomarov, S.Y., 2013, 'Does firm innovativeness enable effective responses to supply chain disruptions? An empirical study', Supply Chain Management. An International Journal 18(6), 604-617.

Green, K.W. Jr, Inman, R.A., Brown, G. \& Willis, T.H., 2005, 'Market orientation: Relation to structure and performance', Journal of Business \& Industrial Marketing 20(6), 276-284. https://doi.org/10.1108/08858620510618110

Green, K.W., Whitten, D. \& Inman, R.A., 2012, 'Aligning marketing strategies throughout the supply chain to enhance performance', Industrial Marketing Management 41(6), 1008-1018. https://doi.org/10.1016/j.indmarman.2012.02.003

Gunasekaran, A., Lai, K.H. \& Cheng, T.E., 2008, 'Responsive supply chain: A competitive strategy in a networked economy', Omega 36(4), 549-564. https://doi.org/ 10.1016/j.omega.2006.12.002

Ha, A.Y., Tong, S. \& Zhang, H., 2011, 'Sharing demand information in competing supply chains with production diseconomies', Management Science 57(3), 566-581. https://doi.org/10.1287/mnsc.1100.1295

Hair, J.F., Black, W.C., Babin, B.J. \& Anderson, R.E., 2010, Multivariate data analysis: A global perspective, Pearson, Upper Saddle River, NJ.

Hall, D.C. \& Saygin, C., 2012, 'Impact of information sharing on supply chain performance, The International Journal of Advanced Manufacturing Technology 58(1-4), 397-409. https://doi.org/10.1007/s00170-011-3389-0

He, H. \& Baruch, Y., 2010, 'Organisational identity and legitimacy under major environmental changes: Tales of two UK building societies', British Journal of Management 21(1), 44-62. https://doi.org/10.1111/j.1467-8551.2009.00666.x

Hess, A.M. \& Rothaermel, F.T., 2011, 'When are assets complementary? Star scientists, strategic alliances, and innovation in the pharmaceutical industry', Strategic Management Journal 32, 895-909. https://doi.org/10.1002/smj.916

Hoejmose, S.U., Roehrich, J.K. \& Grosvold, J., 2014, 'Is doing more doing better? The relationship between responsible supply chain management and corporate
reputation', Industrial Marketing Management 43(1), 77-90. https://doi.org/ reputation', Industrial Marketing
10.1016/j.indmarman.2013.10.002

Hult, G.T.M., Craighead, C.W. \& Ketchen Jr., D.J., 2010, 'Risk uncertainty and supply chain decisions: A real options perspective', Decision Sciences 41(3), 435-458. https://doi.org/10.1111/j.1540-5915.2010.00276.x

Human, G. \& Naudé, P., 2009, 'Exploring the relationship between network competence, network capability and firm performance: A resource-based perspective in an emerging economy. Management dynamics', Journal of the Southern African Institute for Management Scientists 18(1), 2-14.

Industrial Development Corporation, 2016, Economic overview: Recent developments in the global and South African economies, viewed 18 March 2018, from https:// www.idc.co.za/images/download-files/research-reports/IDC-R-I-publicationEconomicOverview-March2016.pdf

Ireland, R. \& Bruce, R., 2000, 'CPFR: Only the beginning of collaboration', Supply Chain Management Review 4(4), 80-88.

Iyer, K.N., Germain, R. \& Claycomb, C., 2009, 'B2B e-commerce supply chain integration and performance: A contingency fit perspective on the role of environment Information \& Management 46(6), 313-322. https://doi.org/10.1016/j.im.2009. 06.002 
Jauhari, V., 2009, 'Institutional context for IT use in the automotive industry: A case study on the market leader in India's passenger vehicle sector', in Technological Innovation Across Nations, pp. 65-93. Springer, Berlin, Heidelberg.

Jiang, Z., Stephan, C. \& Naudé, H.P., 2011, 'Supplier relationship management in the construction industry: The effects of trust and dependence', Journal of Business \& Industrial Marketing 27(1), 3-15. https://doi.org/10.1108/08858621211188920

Jonsson, P. \& Mattsson, S.A., 2013, 'The value of sharing planning information in supply chains', International Journal of Physical Distribution \& Logistics Management 43(4), 282-299. https://doi.org/10.1108/IJPDLM-07-2012-0204

Khajavi, S.H., Partanen, J. \& Holmström, J., 2014, 'Additive manufacturing in the spare parts supply chain', Computers in Industry 65(1), 50-63. https://doi.org/10.1016/j. compind.2013.07.008

Klein, R., Rai, A. \& Straub, D.W., 2007, 'Competitive and cooperative positioning in supply chain logistics relationships', Decision Sciences 38(4), 611-646. https://doi. org/10.1111/j.1540-5915.2007.00172.x

Kline, R.B., 2010, Principles and practice of structural equation modelling, 3rd edn., Guilford Press, New York.

Koçoğlu, İ., İmamoğlu, S.Z., Ince, H. \& Keskin, H., 2011, 'The effect of supply chain integration on information sharing: Enhancing the supply chain performance', Procedia-Social \& Behavioral Sciences 24, 1630-1649. https://doi.org/10.1016/j. sbspro.2011.09.016

KPMG, 2013, Challenges facing supply chains in South Africa, viewed 19 August 2017, from https://www.sablog.kpmg.co.za/2013/12/challenges-facing-supply-chainssouth-africa/

Laan, A., Noorderhaven, N., Voordijk, H. \& Dewulf, G., 2011, 'Building trust in construction partnering projects: An exploratory case-study', Journal of Purchasing and Supply Management 17(2), 98-108. https://doi.org/10.1016/j.pursup.2010. 11.001

Lai, C.S., Chen, C.S., Chiu, C.J. \& Pai, D.C., 2011, 'The impact of trust on the relationship between inter-organisational collaboration and product innovation performance', Technology Analysis \& Strategic Management 23(1), 65-74. https://doi.org/10.10 Technology Analysis \& Strategi
80/09537325.2011.537107

Lai, K.H., Wong, C.W. \& Cheng, T.C.E., 2010, 'Bundling digitised logistics activities and its performance implications', Industrial Marketing Management 39(2), 273-286. https://doi.org/10.1016/j.indmarman.2008.08.002

La Londe, B.J. \& Masters, J.M., 1994, 'Emerging logistics strategies: Blueprints for the next century', International Journal of Physical Distribution \& Logistics Management 24(7), 35-47. https://doi.org/10.1108/09600039410070975

Lambert, D.M., 2014, Supply chain management: Processes, partnerships, performance, 4th edn., Supply Chain Management Institute, Tyne and Wear, UK.

Lambert, D.M., Cooper, M.C. \& Pagh, J.D., 1998, 'Supply chain management: Implementation issues and research opportunities', The International Journal of Logistics Management 9(2), 1-20. https://doi.org/10.1108/09574099810805807

Lau, E. \& Rowlinson, S., 2009, 'Interpersonal trust and inter-firm trust in construction projects', Construction Management \& Economics 27(6), 539-554. https://doi. org/10.1080/01446190903003886

Lee, H., Seo, Y. \& Dinwoodie, J., 2016, 'Supply chain integration and logistics performance: The role of supply chain dynamism', International Journal of Logistics Management 27(3), 1-15. https://doi.org/10.1108/IJLM-06-2015-0100

Lee, J.J., 2013, 'Dancing with the enemy? Relational hazards and the contingent value of repeat exchanges in M\&A markets', Organisation Science 24(4), 1237-1256. https://doi.org/10.1287/orsc.1120.0786

Lee, J.Y., Swink, M. \& Pandejpong, T., 2011, 'The roles of worker expertise, information sharing quality, and psychological safety in manufacturing process innovation: An intellectual capital perspective', Production and Operations Management 20(4) 556-570. https://doi.org/10.1111/j.1937-5956.2010.01172.x

Leuschner, R., Rogers, D.S. \& Charvet, F.F., 2013, 'A meta-analysis of supply chain integration and firm performance', Journal of Supply Chain Management 49(2), 34-57. https://doi.org/10.1111/jscm.12013

Li, S. \& Lin, B., 2006, 'Accessing information sharing and information quality in supply chain management', Decision Support Systems 42(3), 1641-1656. https://doi. chain management', Decision
org/10.1016/j.dss.2006.02.011

Li, S., Ragu-Nathan, B., Ragu-Nathan, T.S. \& Rao, S.S., 2006, 'The impact of supply chain management practices on competitive advantage and organisational performance', Omega 34(2), 107-124. https://doi.org/10.1016/j.omega.2004.08.002

Li, Y., Ye, F. \& Sheu, C., 2014, 'Social capital, information sharing and performance: Evidence from China', International Journal of Operations \& Production Management 34(11), 1440-1462. https://doi.org/10.1108/IJOPM-03-2013-0132 $\mathrm{Li}, \mathrm{Z}$. \& Gao, Y., 2011, 'Information sharing pattern of agricultural products supply
chain based on E-commerce', 2011 International Conference on E-Business and E-Government (ICEE), Shangai, China, May 06-08 2011, pp. 540-548.

Lin, F.R., Huang, S.H. \& Lin, S.C., 2002, 'Effects of information sharing on supply chain performance in electronic commerce', Engineering Management, IEEE Transactions on 49(3), 258-268. https://doi.org/10.1109/TEM.2002.803388

Lotfi, Z., Mukhtar, M., Sahran, S. \& Taei Zadeh, A., 2013, 'Information sharing in supply chain management', Procedia Technology 11, 298-304. https://doi.org/10.1016/j. protcy.2013.12.194

Lumineau, F. \& Quélin, B.V., 2012, 'An empirical investigation of inter-organisational opportunism and contracting mechanisms', Strategic Organisation 10(1), 55-84. https://doi.org/10.1177/1476127011434798

Lun, Y.V., Lai, K.H., Wong, C.W. \& Cheng, T.C.E., 2016, 'Greening propensity and performance implications for logistics service providers', Transportation Research Part E: Logistics and Transportation Review 74, 50-62.
Luzzini, D., Brandon-Jones, E., Brandon-Jones, A. \& Spina, G., 2015, ‘From sustainability commitment to performance: The role of intra-and inter-firm collaborative capabilities in the upstream supply chain' International Journal of Production Economics 165, 51-63. https://doi.org/10.1016/j.ijpe.2015.03.004

Madlberger, M. \& Roztocki, N., 2010, 'Digital cross-organisational collaboration: A meta-triangulation review', European Journal of Information Systems 23, 418-428.

Mansoori, S., Jamshidinavid, B. \& Hashemi, S.R., 2014, 'The impact of supply chain integration on supply chain performance', Journal of Applied Environmental \& Biological Sciences 4(3), 229-237.

Manu, E., Ankrah, N., Chinyio, E. \& Proverbs, D., 2015, 'Trust influencing factors in main contractor and subcontractor relationships during projects', Internationa Journal of Project Management 33(7), 1495-1508. https://doi.org/10.1016/j. ijproman.2015.06.006

Martin, S., 2009, 'Networking for gold: A multi-level analysis to explain network organising dynamics', unpublished doctoral thesis, Massey University, Albany, New Zealand.

Matanda, M.J. \& Freeman, S., 2009, 'Effect of perceived environmental uncertainty on exporter-importer inter-organisational relationships and export performance improvement', International Business Review 18(1), 89-107. https://doi.org/ 10.1016/j.ibusrev.2008.12.004

Mayer, R.C., Davis, J.H. \& Schroorman, F.D., 2007, 'An integrative model of organisational trust', in R.M. Kramer (ed.), Organisational trust: A reader, Oxford University Press, Oxford, pp. 82-108.

McCarthy, T.M. \& Golicic, S.L., 2002, 'Implementing collaborative forecasting to improve supply chain performance', International Journal of Physical Distribution \& Logistics Management 32(6), 431-454. https://doi.org/10.1108/096000302104 37960

Mentzer, J.T., Foggin, J.H. \& Golicic, S.L., 2000, 'Collaboration: The enablers, impediments, and benefits', Supply Chain Management Review 4(4), 52-58.

Merlino, M. \& Sproǵe, I., 2017, 'The augmented supply chain', Procedia Engineering 178, 308-318. https://doi.org/10.1016/j.proeng.2017.01.053

Merschmann, U. \& Thonemann, U.W., 2011, 'Supply chain flexibility, uncertainty and firm performance: An empirical analysis of German manufacturing firms', International Journal of Production Economics 130(1), 43-53. https://doi.org/ 10.1016/j.ijpe.2010.10.013

Min, H. \& Yu, W.B.V., 2008, 'Collaborative planning, forecasting and replenishment: Demand planning in supply chain management', International Journal of Information Technology \& Management 7(1), 4-20. https://doi.org/10.1504/ IJITM.2008.015886

Mishra, P. \& Sharma, R.K., 2014, 'Benchmarking SCM performance and empirical analysis: A case from paint industry', Logistics Research 7(1), 1-16. https://doi. org/10.1007/s12159-014-0113-0

Mourtzis, D., 2011, 'Internet based collaboration in the manufacturing supply chain', CIRP, Journal of Manufacturing Science \& Technology 4(3), 296-304. https://doi. org/10.1016/j.cirpj.2011.06.005

Naude, M.J., 2013, 'Supply chain challenges in the South African automotive sector: Do location, size and age matter?', South African Journal of Economic and Management Sciences 16(4), 407-417. https://doi.org/10.4102/sajems.v16i4.411

Naude, M.J. \& Badenhorst-Weiss, J.A., 2011, 'Supply chain management problems at South African automotive component manufacturers', Southern African Business Review 15(1), 70-99.

Nel, E., 2017, 'South Africa's manufacturing economy: Problems and performance', in C.M. Rogerson (ed.), Geography and economy in South Africa and its neighbours, pp. 81-94, Routledge, London.

Nunnally, J.C. \& Bernstein, I.H., 1994, 'The assessment of reliability', Psychometric Theory 3, 248-292.

Nyaga, G.N., Whipple, J.M. \& Lynch, D.F., 2010, 'Examining supply chain relationships: Do buyer and supplier perspectives on collaborative relationships differ?', Journal of Operations Management 28(2), 101-114. https://doi.org/10.1016/j.jom. of Operations

Outlook, G.M., 2015, 'Preparing for battle: Manufacturers get ready for transformation' KPMG 2015, 34p, viewed 12 March 2018, from https://www.kpmg.com/CN/en/ IssuesAndInsights/ArticlesPublications/Documents/Global-ManufacturingOutlook-O-201506.pdf

Özer, Ö., Zheng, Y. \& Chen, K.Y., 2011, 'Trust in forecast information sharing', Management Science 57(6), 1111-1137. https://doi.org/10.1287/mnsc.1110.1334

Özer, Ö., Zheng, Y. \& Ren, Y., 2014, 'Trust, trustworthiness, and information sharing in supply chains bridging China and the United States', Management Science 60(10), 2435-2460. https://doi.org/10.1287/mnsc.2014.1905

Palanski, M.E., Kahai, S.S. \& Yammarino, F.J., 2011, 'Team virtues and performance: An examination of transparency, behavioral integrity, and trust', Journal of Business Ethics 99(2), 201-216. https://doi.org/10.1007/s10551-010-0650-7

Pandey, V., Garg, S. \& Shankar, R., 2010, 'Impact of information sharing on competitive strength of Indian manufacturing enterprises: An empirical study', Business Process Management Journal 16, 226-243. https://doi.org/10.1108/14637151011035570 Patel, H., Pettitt, M. \& Wilson, J.R., 2012, 'Factors of collaborative working: A
framework for a collaboration model', Applied Ergonomics 43(1), 1-26. https:// doi.org/10.1016/j.apergo.2011.04.009

Pillay, K., 2015, Enhancing manufacturing competitiveness in South Africa, Deloitte manufacturing competitiveness report, viewed 22 September 2016, from http:// www2.deloitte.com/content/dam/Deloitte/dk/Documents/manufacturing/ manufacturing-competitiveness-South-africa.pdf

Prajogo, D. \& Olhager, J., 2012, 'Supply chain integration and performance: The effects of long-term relationships, information technology and sharing, and logistics integration', International Journal of Production Economics 135, 514-522. https:// doi.org/10.1016/j.ijpe.2011.09.001 
Qrunfleh, S. \& Tarafdar, M., 2014, 'Supply chain information systems strategy: Impacts on supply chain performance and firm performance', International Journal of on supply chain performance and firm performance, International Journal of
Production Economics 147, 340-350. https://doi.org/10.1016/j.ijpe.2012.09.018

Rajaguru, R. \& Matanda, J.M., 2009, 'Influence of inter-organisational integration on business performance: The mediating role of organisational-level supply chain functions', Journal of Enterprise Information Management 22(4), 456-467. https://doi.org/10.1108/17410390910975059

Rajaguru, R. \& Matanda, M.J., 2013, 'Effects of inter-organisational compatibility on supply chain capabilities: Exploring the mediating role of inter-organisational information systems (IOIS) integration', Industrial Marketing Management 42(4), 620-632. https://doi.org/10.1016/j.indmarman.2012.09.002

Ramanathan, U., 2014, 'Performance of supply chain collaboration: A simulation study', Journal of Expert Systems with Applications 41, 210-220. https://dol. org/10.1016/j.eswa.2013.07.022

Reddy, V., 2016, Skills supply \& demand for South Africa. Presentation made at the Labour Market Intelligence Partnership Colloquium, 28 September, Johannesbur South Africa, viewed 18 March 2018, from www.Imip.org.za/sites/default/ files/documentfiles/Vijay\%20Reddy\%20_LMIP_Presentation_LMIPColloquium_ 28Sept2016_final.pdf.

Rensburg, S.M., Nieuwenhuizen, C. \& De Bruyn, H.E.C., 2014, 'Inter-organisational relationships with large enterprises as a source of competitive advantage for small and medium enterprises', Journal of Contemporary Management 11, 613-636.

Sánchez, J.M., Vélez, M.L. \& Álvarez-Dardet, C., 2013, 'Evolving functions of interorganisational governance mechanisms', Managerial \& Decision Economics 34(3-5), 301-318. https://doi.org/10.1002/mde.2591

Schilke, O. \& Cook, K.S., 2013, 'A cross-level process theory of trust development in inter-organisational relationships', Strategic Organisation 11(3), 281-303. https:// doi.org/10.1177/1476127012472096

Schoenherr, T. \& Swink, M., 2012, 'Revisiting the arcs of integration: Cross-validations and extensions', Journal of Operations Management 30(1-2), 99-115. https://doi. org/10.1016/j.jom.2011.09.001

Scholten, K. \& Schilder, S., 2015, 'The role of collaboration in supply chain resilience', Supply Chain Management: An International Journal 20(4), 471-484. https://doi. org/10.1108/SCM-11-2014-0386

Seuring, S., 2013, 'A review of modeling approaches for sustainable supply chain management', Decision Support Systems 54(4), 1513-1520. https://doi.org/ 10.1016/j.dss.2012.05.053

Seuring, S. \& Müller, M., 2008, 'From a literature review to a conceptual framework for sustainable supply chain management', Journal of Cleaner Production 16(15), 1699-1710. https://doi.org/10.1016/j.jclepro.2008.04.020

Sezen, B., 2008, 'Relative effects of design, integration and information sharing on supply chain performance', Supply Chain Management. An International Journa 13(3), 233-240. https://doi.org/10.1108/13598540810871271

Simangunsong, E., Hendry, L.C. \& Stevenson, M., 2012, 'Supply-chain uncertainty: A review and theoretical foundation for future research', International Journal of Production Research 50(16), 4493-4523. https://doi.org/10.1080/00207543.201 1.613864

Simatupang, T.M. \& Sridharan, R., 2002, 'The collaborative supply chain', Internationa Journal of Logistics Management 13(1), 15-30. https://doi.org/10.1108/095740 90210806333

Simchi-Levi, D. \& Kaminsky, P., 2008, Designing and managing the supply chain Concepts, strategies and case studies, 3rd edn., McGraw Hill/Irwin, Boston, MA.

Singh, R.K. \& Acharya, P., 2013, 'Supply chain flexibility: A frame work of research dimensions', Global Journal of Flexible Systems Management 14(3), 157-166. https://doi.org/10.1007/s40171-013-0039-4

Skipper, J.B. \& Hanna, J.B., 2009, 'Minimising supply chain disruption risk through enhanced flexibility', International Journal of Physical Distribution \& Logistic Management 39(5), 404-427. https://doi.org/10.1108/09600030910973742

Sodhi, M.S., Son, B.G. \& Tang, C.S., 2012, 'Researchers' perspectives on supply chain risk management', Production \& Operations Management 21(1), 1-13. https:// doi.org/10.1111/j.1937-5956.2011.01251.x

Soosay, C.A., Hyland, P.W. \& Ferrer, M., 2008, 'Supply chain collaboration: Capabilities for continuous innovation', Supply Chain Management. An International Journa 13(2), 160-169. https://doi.org/10.1108/13598540810860994

Sorrentino, F. \& Garraffo, F., 2012, 'Explaining performing R\&D through alliances: Implications for the business model of Italian dedicated biotech firms', Journal of Management \& Governance 16, 449-475. https://doi.org/10.1007/s10997-0109159-9

South African Government Gazette, 2003, No 26 National Small Business Amendment Act, vol. 461, Parliament of the Republic of South Africa, Cape Town, pp. 1-10.

Stadtler, H., Kilger, C. \& Meyr, H. (eds.), 2015, 'Supply chain management and advanced planning, Springer, Berlin, Heidelberg.

Statistics South Africa, 2016a, Economic growth, viewed 22 September 2016, from http://www.statssa.gov.za/?page_id=735\&id=1

Statistics South Africa, 2016b, South African manufacturing production and the rand: (An update), viewed 18 March 2018, from http://www.statssa.gov.za/?p=8260

Stevenson, M. \& Spring, M., 2007, 'Flexibility from a supply chain perspective: Definition and review', International Journal of Operations \& Production Management 27(7), 685-713. https://doi.org/10.1108/01443570710756956
Stevenson, M. \& Spring, M., 2009, 'Supply chain flexibility: An inter-firm empirical study', International Journal of Operations \& Production Management 29(9), study', Int $946-971$.

Swafford, P.M., Ghosh, S. \& Murthy, N., 2008, 'Achieving supply chain agility through IT integration and flexibility', International Journal of Production Economics 116(2), 288-297. https://doi.org/10.1016/j.ijpe.2008.09.002

Trading Economics, 2016, South Africa GDP Annual Growth Rate: 1994-2016, viewed 22 September 2016, from http://www.tradingeconomics.com/south-africa/gdpgrowth-annual

Trkman, P., Budler, M. \& Groznik, A., 2015, 'A business model approach to supply chain management', Supply Chain Management: An International Journal 20(6), 587602. https://doi.org/10.1108/SCM-06-2015-0219

Varoutsa, E. \& Scapens, R.W., 2015, 'The governance of inter-organisational relationships during different supply chain maturity phases', Industrial Marketing Management 46, 68-82. https://doi.org/10.1016/j.indmarman.2015.01.006

Vijayasarathy, L.R., 2010, 'Supply integration: An investigation of its multidimensionality and relational antecedents', International Journal of Production Economics 124(2), 489-505. https://doi.org/10.1016/j.ijpe.2010.01.010

Vilko, J., Ritala, P. \& Edelmann, J., 2014, 'On uncertainty in supply chain risk management', The International Journal of Logistics Management 25(1), 3-19. https://doi.org/10.1108/IJLM-10-2012-0126

Wang, G., Dou, W., Zhu, W. \& Zhou, N., 2015, 'The effects of firm capabilities on external collaboration and performance: The moderating role of market turbulence', Journal of Business Research 68(9), 1928-1936. https://doi.org/ 10.1016/j.jbusres.2015.01.002

Weber, M., Hiete, M., Lauer, L. \& Rentz, O., 2010, 'Low cost country sourcing and its effects on the total cost of ownership structure for a medical devices manufacturer', Journal of Purchasing \& Supply Management 16(1), 4-16. https:// doi.org/10.1016/j.pursup.2009.06.001

West, S.G., Taylor, A.B. \& Wu, W., 2012, 'Model fit and model selection in structural equation modeling', in R.H. Hoyle (ed.), Handbook of structural equation modeling, pp. 209-231, Guilford Press, New York.

Whipple, J.M. \& Russell, D., 2007, 'Building supply chain collaboration: A typology of collaborative approaches', The International Journal of Logistics Managemen 18(2), 174-196. https://doi.org/10.1108/09574090710816922

Wieczorek, E., 2012, 'Supply chain risks', in C. Raimbault \& A. Barr (eds.), Emerging risks. A strategic management guide, pp. 141-181, Gowee, Surrey.

Wong, C.Y., Boon-Itt, S. \& Wong, C.W., 2011, 'The contingency effects of environmental uncertainty on the relationship between supply chain integration and operational performance', Journal of Operations Management 29(6), 604-615. https://doi. performance,' Journal of Operation
org/10.1016/j.jom.2011.01.003

Wu, L., Chuang, C.H. \& Hsu, C.H., 2014, 'Information sharing and collaborative behaviors in enabling supply chain performance: A social exchange perspective' International Journal of Production Economics 148, 122-132. https://doi.org/ 10.1016/j.ijpe.2013.09.016

Yang, C.F. \& Lai, C.S., 2012, 'Relationship learning from organisational knowledge stores', Journal of Business Research 65(3), 421-428. https://doi.org/10.1016/j. jbusres.2011.10.001

Yilmaz, H., Çemberci, M. \& Uca, N., 2016, 'The role of collaborative advantage for analyzing the effect of supply chain collaboration on firm performance', International Journal of Commerce and Finance 2(1), 157.

Youn, S., Yang, M.G.M., Hong, P. \& Park, K., 2013, 'Strategic supply chain partnership environmental supply chain management practices, and performance outcomes: An empirical study of Korean firms', Journal of Cleaner Production 5, 121-130. https://doi.org/10.1016/j.jclepro.2011.09.026

Yu, W., Jacobs, M.A., Salisbury, W.D. \& Enns, H., 2013, 'The effects of supply chain integration on customer satisfaction and financial performance: An organisational learning perspective', International Journal of Production Economics 146(1), 346-358. https://doi.org/10.1016/j.ijpe.2013.07.023

Yu, Z., Yan, H. \& Edwin Cheng, T.C., 2001, 'Benefits of information sharing with supply chain partnerships', Industrial Management \& Data Systems 101(3), 114-121. https://doi.org/10.1108/02635570110386625

Zailani, S. \& Rajagopal, P., 2005, 'Supply chain integration and performance: US versus East Asian companies', Supply Chain Management: An International Journal 10(5), 379-393. https://doi.org/10.1108/13598540510624205

Zhang, T.Z. \& Lu, S.C., 2011, 'Study on win-win of coordinating supply chain', paper presented at the 2011 International Conference on Business Management and Electronic Information (BMEI), Guangzhou, China, May 13-15.

Zhao, X., Huo, B., Selen, W. \& Yeung, J.H.Y., 2011, 'The impact of internal integration and relationship commitment on external integration', Journal of Operations Management 29, 17-32. https://doi.org/10.1016/j.jom.2010.04.004

Zhao, X., Xie, J. \& Zhang, W.J., 2002, 'The impact of information sharing and ordering co-ordination on supply chain performance', Supply Chain Management: An
International Journal 7(1), 24-40. https://doi.org/10.1108/13598540210414364

Zhou, H. \& Benton, W.C., 2007, 'Supply chain practice and information sharing', Journal of Operations Management 25(6), 1348-1365. https://doi.org/10.1016/j. jom.2007.01.009

Ziakas, V. \& Costa, C.A., 2010, 'Explicating inter-organisational linkages of a host community's events network', International Journal of Event \& Festival Management 1(2), 132-147. https://doi.org/10.1108/17852951011056919 


\section{Appendix 1}

\section{Measurement scales used in the study Supply chain dynamism}

Indicate your views regarding the supply chain in which your firm operates.

Five-point scale: 1 = strongly disagree; 2 = disagree; 3 = neither agree nor disagree; 4 = agree; 5 = strongly disagree.

- Our supply chain is subject to random changes in products.

- Our supply chain experiences rapid changes in technology.

- Our supply chain experiences frequent changes in production methods.

- Our supply chain experiences random changes in the demand and supply of products.

\section{Information sharing}

Indicate your views regarding information sharing in the supply chain in which your firm operates.

Five-point scale: 1 = strongly disagree; 2 = disagree; 3 = neither agree nor disagree; 4 = agree; 5 = strongly disagree.

- Our trading partners are informed in advance of changing needs.

- Our trading partners share proprietary information with us.

- Our trading partners keep us fully informed about issues that affect our business.

- Our trading partners share business knowledge of core business with us.

- Our trading partners exchange information that helps establishment of business planning.

- Our trading partners keep each other informed about events or changes that may affect the other partners.

\section{Inter-organisational relationships}

Indicate your views regarding relationships in the supply chain in which your firm operates.

Five-point scale: 1 = strongly disagree; 2 = disagree; 3 = neither agree nor disagree; 4 = agree; 5 = strongly disagree.

- Our trading partners have been open and honest in dealing with us.

- Our trading partners respect the confidentiality of the information they receive from us.

- Transactions with our trading partners do not have to be monitored.

- Inter-organisational systems are used to link with our trading partners.

- Our trading partners offer assistance when need arises.

\section{Supply chain performance}

Indicate your views regarding the performance of the supply chain in which your firm operates.

Five-point scale: 1 = strongly disagree; 2 = disagree; 3 = neither agree nor disagree; 4 = agree; 5 = strongly disagree.

- Our supply chain has the ability to deliver zero defects to final customers.

- Our supply chain has the ability to deliver value-added services to final customers.

- Our supply chain has the ability to eliminate late, damaged and incomplete orders to final customers.

- Our supply chain has the ability to quickly solve problems experienced by customers.

- Our supply chain has the ability to deliver precise quantities. 